\title{
Therapeutic options targeting angiogenesis in nonsmall cell lung cancer
}

\author{
Lucio Crinò and Giulio Metro
}

\begin{abstract}
Affiliations: Division of Medical Oncology, Santa Maria della Misericordia Hospital, Azienda Ospedaliera di
\end{abstract} Perugia, Perugia, Italy.

Correspondence: L. Crinò, Division of Medical Oncology, Santa Maria della Misericordia Hospital, 06100 Perugia, Italy. E-mail: lucio.crinodospedale.perugia.it

ABSTRACT There is a major unmet medical need for effective and well-tolerated treatment options for patients with advanced nonsmall cell lung cancer (NSCLC), in both first-line and relapsed/refractory settings. Experimental evidence has validated signalling pathways that regulate tumour angiogenesis, including the vascular endothelial growth factor (VEGF), platelet-derived growth factor (PDGF) and fibroblast growth factor (FGF) pathways, as valid anti-cancer drug targets. However, to date, bevacizumab (an anti-VEGF monoclonal antibody) is the only antiangiogenic agent to be approved for the treatment of NSCLC. Many other agents, including antibodies, small-molecule tyrosine kinase inhibitors and vascular disrupting agents, have been assessed in phase III trials but have generally failed to demonstrate clinically meaningful benefits. This lack of success probably reflects the redundancy of proangiogenic pathways and the molecular and clinical heterogeneity of NSCLC.

In this review we summarise recently completed and ongoing randomised clinical trials of emerging antiangiogenic agents in patients with NSCLC. We highlight recent promising data with agents that simultaneously inhibit multiple proangiogenic pathways, including the PDGF and FGF pathways, as well as the VEGF pathway. Finally, we discuss the outlook for antiangiogenic agents in NSCLC, emphasising the need for clinically validated prognostic and predictive biomarkers to identify patients most likely to respond to therapy.

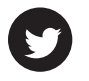

@ERSpublications

A review of recent trials with antiangiogenic agents in NSCLC highlighting promising data with triple kinase inhibitors http://ow.ly/seIho

\section{Introduction}

Most patients with nonsmall cell lung cancer (NSCLC) present with advanced inoperable disease; the prognosis for these patients is extremely poor. Indeed, 5-year survival rates for patients diagnosed with stage IIIB or IV NSCLC are only $5 \%$ and $1 \%$, respectively [1]. The standard first-line therapy for advanced NSCLC comprises platinum-based combination therapy, which prolongs survival, controls symptoms and improves quality of life, versus best supportive care in patients with good performance status [2]. A minority of patients may receive "personalised" first-line therapy according to the identification of "druggable" genetic alterations in tumour tissue. For example, patients with activating mutations in the epidermal growth factor receptor (EGFR) gene should receive an EGFR small-molecule inhibitor such as erlotinib (Tarceva; Hoffmann-La Roche Ltd, Basel, Switzerland), gefitinib (Iressa; AstraZeneca, London, UK) or afatinib (Giotrif; Boehringer Ingelheim, Ingelheim, Germany). Patients with rearrangements of the anaplastic lymphoma kinase $(A L K)$ gene may receive the ALK inhibitor crizotinib (Xalkori; Pfizer, New York, NY, USA).

Received: Dec 102013 | Accepted after revision: Dec 192013

Conflict of interest: None declared.

Provenance: Publication of this peer-reviewed article was supported by Boehringer Ingelheim, Germany (article sponsor, European Respiratory Review issue 131).

Copyright OERS 2014. ERR articles are open access and distributed under the terms of the Creative Commons Attribution Non-Commercial Licence 3.0. 
Regardless of the first-line treatment used, clinical outcomes in patients with IIIB/IV NSCLC are generally poor. Most patients with stage IIIB/IV NSCLC experience disease progression within 4-6 months of discontinuing first-line chemotherapy [3]; those who receive EGFR inhibitors generally become resistant to therapy within 10-14 months [4]. Few effective second-line treatment options are available to patients who progress after first-line therapy. Treatment guidelines recommend docetaxel or pemetrexed (the latter in patients with non-squamous histology only) [2]. Erlotinib may be a further option as second- or third-line treatment [2]. However, survival benefits with available second-line agents are modest [5-7]. Furthermore, approximately $50 \%$ of patients who fail first-line therapy go on to receive second-line chemotherapy [8]. Hence, there is an urgent need for effective and well-tolerated treatment options for NSCLC in both firstline and relapsed/refractory settings.

In many cancers, including NSCLC, proangiogenic pathways have been established as important and effective therapeutic targets because they are essential for tumour growth, progression and metastasis [9]. Tumour angiogenesis is essential for the development and progression of malignant tumours; it is a highly complex process involving a network of autocrine and paracrine signalling pathways within the tumour and surrounding stromal cells. A key driver of tumour angiogenesis is hypoxia, which stimulates the overproduction of proangiogenic factors relative to antiangiogenic factors (fig. 1) [10, 11].

One of the best characterised proangiogenic pathways is the vascular endothelial growth factor (VEGF) signalling pathway. This comprises six growth factors (VEGFA to E and placental growth factor) and three VEGF receptors (VEGFR1 to 3). Interactions between VEGF ligands and VEGFRs stimulate several downstream signalling cascades that coordinate endothelial cell proliferation, differentiation, permeability and migration in order to stimulate the generation of new blood vessels [12]. The prominent role of the VEGF signalling pathway in tumour angiogenesis prompted the clinical development of angiogenesis inhibitors for the treatment of various cancers, including NSCLC. In general, this has involved two main approaches: 1) high molecular weight, injectable, monoclonal antibodies that block the function of VEGF ligands or receptors; and 2) small-molecule, orally administered tyrosine kinase inhibitors (TKIs) that directly inhibit VEGFRs and their signalling pathways [13]. The proof of principle for VEGF inhibition in NSCLC has been demonstrated in clinical trials of bevacizumab (Avastin; Hoffmann-La Roche Ltd), an anti-VEGF monoclonal antibody. Bevacizumab, in combination with platinum-based chemotherapy, has been shown to improve survival versus chemotherapy alone in a first-line setting in patients with nonsquamous NSCLC [14].

Unfortunately, NSCLC tumours often acquire resistance to antiangiogenic agents because proangiogenic pathways have substantial redundancy, allowing adaptation to bypass the inhibition of a single pathway. Acquired resistance involves a complex myriad of interactions between the tumour cells themselves and cells within the tumour microenvironment, e.g. pericytes, smooth muscle cells, fibroblasts and endothelial cells [15]. Recent intensive research has led to insights into the biology of acquired resistance that may ultimately lead to the development of more effective antiangiogenic agents. Emerging evidence has implicated two key signalling pathways, the fibroblast growth factor (FGF) and platelet-derived growth factor (PDGF) signalling pathways, in adaptive resistance to VEGF therapy [15].

The FGF family includes 22 ligands and five receptors with diverse biological functions, including angiogenesis $[16,17]$. FGF receptors (FGFRs) are known to be overexpressed in many cancer types and, in some cases, have been identified as oncogenes to which tumour cells are addicted [17]. FGFRs have been identified as among the most commonly mutated kinase genes in human cancers, with mutations in FGFR2 and FGFR3 being the most prevalent [17]. Two FGFRs, FGFR1 and 2, are expressed in endothelial cells and activate proangiogenic intracellular signalling pathways, including the phosphatidylinositol 3-kinase and mitogen-activated protein kinase pathways. Like the FGF signalling pathway, the PDGF pathway is integral to the regulation of angiogenesis. Enhanced PDGF expression has been associated with tumourigenesis and angiogenesis [18]. Five dimeric PDGF ligands are released from platelets in response to vascular damage and bind to two PDGF receptors (PDGFRs) ( $\alpha$ and $\beta$ ) expressed on endothelial cells, pericytes and vascular smooth muscle cells $[19,20]$. This activates intracellular signalling cascades (which overlap with the VEGF signalling system) to promote vascular integrity, development and stabilisation.

In this review, we provide an overview of recent advances in the development of antiangiogenic agents for the treatment of NSCLC in both first-line and relapsed/refractory settings focusing on ongoing or recently completed phase III studies of TKIs that simultaneously inhibit multiple proangiogenic pathways.

\section{Antiangiogenic agents in the first-line setting}

\section{Bevacizumab}

To date, bevacizumab is the only antiangiogenic agent approved for the first-line treatment of NSCLC. Its use is restricted to patients with tumours with a non-squamous histology ( $\sim 70 \%$ of patients with NSCLC). 


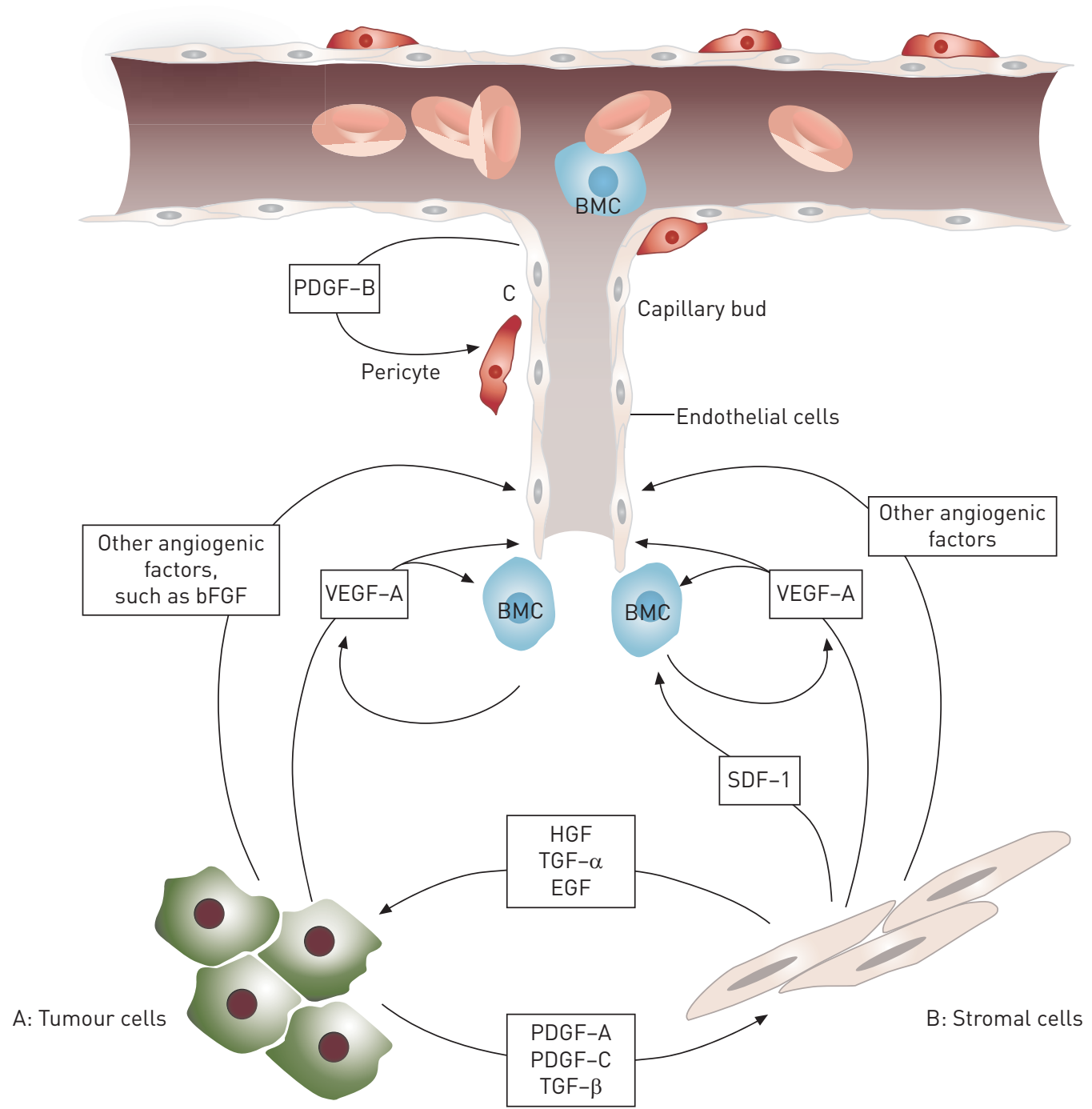

FIGURE 1 Molecular pathways underlying angiogenesis. A: Tumour cells produce vascular endothelial growth factor (VEGF)-A and other angiogenic factors, such as basic fibroblast growth factor (bFGF), angiopoietins, interleukin-8, placental growth factor and VEGF-C. These stimulate resident endothelial cells to proliferate and migrate. B: An additional source of angiogenic factors is the stroma. This is a heterogeneous compartment, comprising fibroblastic, inflammatory and immune cells. Recent studies indicate that tumour-associated fibroblasts produce chemokines, such as stromal cell-derived factor (SDF)-1, which may recruit bone-marrow-derived angiogenic cells (BMC). VEGF-A or placental growth factor may also recruit BMC. Tumour cells may also release stromal cell-recruitment factors, such as platelet-derived growth factor (PDGF)-A, PDGF-C or transforming growth factor (TGF)- $\beta$. A well-established function of tumour-associated fibroblasts is the production of growth/survival factor for tumour cells, such as epidermal growth factor (EGF) receptor ligands, hepatocyte growth factor and heregulin. C: Endothelial cells produce PDGF-B, which promotes recruitment of pericytes in the microvasculature after activation of PDGF receptor- $\beta$. HGF: hepatocyte growth factor. Reproduced from [10] with permission.

Bevacizumab was approved based on two seminal phase III trials (table 1) [14, 21]. In the ECOG (Eastern Cooperative Oncology Group) 4599 trial, 878 patients with non-squamous NSCLC were randomised to receive carboplatin/paclitaxel with or without bevacizumab $\left(15 \mathrm{mg} \cdot \mathrm{kg}^{-1}\right.$ intravenously) [14]. In this trial, bevacizumab was associated with significant prolongation of both overall survival (12.3 months versus 10.3 months, hazard ratio (HR) for death: $0.79 ; \mathrm{p}=0.003$ ) and progression-free survival (PFS) (6.2 months versus 4.5 months, HR 0.66; $\mathrm{p}<0.001)$ versus placebo. However, in a retrospective sub-analysis of elderly patients (aged $\geqslant 70$ years), there was no significant improvement in overall survival or PFS [29]. Grade $\geqslant 3$ adverse events were significantly higher in the bevacizumab arm and included a number of toxicities that are often associated with VEGF inhibition including neutropenia, febrile neutropenia, bleeding events, hypertension and proteinuria. In the AVAiL (Avastin in Lung Cancer) trial, 1043 patients with nonsquamous NSCLC were randomised to receive cisplatin/gemcitabine with or without bevacizumab 
$\left(7.5 \mathrm{mg} \cdot \mathrm{kg}^{-1}\right.$ or $15 \mathrm{mg} \cdot \mathrm{kg}^{-1}$ ) [21]. As with ECOG 4599, bevacizumab was associated with improvement in PFS (at both doses) versus placebo $\left(7.5 \mathrm{mg} \cdot \mathrm{kg}^{-1}: 6.7\right.$ months versus 6.1 months, $\mathrm{p}=0.003 ; 15 \mathrm{mg} \cdot \mathrm{kg}^{-1}$ : 6.5 months versus 6.1 months, $\mathrm{p}=0.03$ ). In contrast to ECOG 4599, improved PFS was observed in elderly patients [30]. However, there was no significant difference in overall survival between treatment arms [22]. The most common grade $\geqslant 3$ adverse events were myelosuppression events.

\section{TABLE 1 Recent phase III trials assessing antiangiogenic agents in a first-line setting}

\begin{tabular}{|c|c|c|c|c|c|}
\hline $\begin{array}{l}\text { Agent and study name } \\
\text { [ref.] }\end{array}$ & Target (s) & Study design & Overall response rate & Progression-free survival & Overall survival \\
\hline
\end{tabular}

\section{Monoclonal antibodies}

Bevacizumab; ECOG $4599[14]$ VEGF GF

Stage IIIB/IV non-squamous
NSCLC
Patients randomised to:
carboplatin/paclitaxel ( $\mathrm{n}=444$ ) or
carboplatin/paclitaxel +
bevacizumab ( $\left.15 \mathrm{mg} \cdot \mathrm{kg}^{-1} ; \mathrm{n}=434\right)$
Primary end-point: overall survival
Stage IIIB/IV non-squamous
NSCLC
Patients randomised to: cisplatin/
gemcitabine $(\mathrm{n}=347)$, cisplatin/
gemcitabine + bevacizumab
(7.5 $\left.\mathrm{mg}^{-1} \mathrm{~kg}^{-1} ; \mathrm{n}=345\right)$ or cisplatin/
gemcitabine + bevacizumab
(15 $\left.\mathrm{mg} \cdot \mathrm{kg}^{-1} ; \mathrm{n}=351\right)$
Primary end-point:
progression-free survival

\section{Multi-targeted antiangiogenic orally administered TKIs} Cediranib; BR24 [23]

Cediranib; BR29 [24]

Sorafenib; ESCAPE [25]

Sorafenib; NExUS [26]

Motesanib; MONET1 [27]

\section{Vascular disrupting \\ agents \\ Vadimezan; \\ ATTRACT-1 [28]}

VEGFR-2-3, PDGFR- $\beta$, c-kit, Raf and flt-3

VEGFR-2-3, PDGFR- $\beta, c-k i t$, Raf and flt-3

VEGFR-1-3, PDGFR- $\beta, c-k i$ and RET

VEGFR-1-3, Stage IIIB/IV NSCLC all histologies GFR- $\beta$, FGFR-1 Patients randomised to: carboplatin/paclitaxel $(n=125)$ or carboplatin/paclitaxel + cediranib

(30 $\mathrm{mg} \cdot$ day $^{-1} ; \mathrm{n}=126$ ) Primary end-point: progressionfree survival

VEGFR-1-3, Stage IIIB/IV NSCLC all histologies PDGFR- $\beta$, FGFR-1 Patients randomised to: carboplatin/paclitaxel or carboplatin/ paclitaxel + cediranib (20 mg $\cdot$ day $\left.^{-1}\right)$ Primary end-point: overall survival

Stage IIIB/IV NSCLC all histologies Patients randomised to: carboplatin/paclitaxel $(n=462)$ or carboplatin/paclitaxel + sorafenib ( $400 \mathrm{mg} ; \mathrm{n}=464$ )

Primary end-point: overall survival Stage IIIB/IV non-squamous

$$
\text { NSCLC }
$$

Patients randomised to: gemcitabine/cisplatin ( $n=387$ ) or gemcitabine/cisplatin + sorafenib ( 400 mg; $n=385$ )

Primary end-point: overall survival Stage IIIB/IV non-squamous NSCLC

Patients randomised to: carboplatin/paclitaxel $(n=549)$ or carboplatin/paclitaxel + motesanib (125 mg; $n=541$ )

Primary end-point: overall survival

Stage IIIB/IV NSCLC all histologies Patients randomised to: carboplatin/paclitaxel $(n=650)$ or carboplatin/paclitaxel + vadimezan (1800 $\mathrm{mg} \cdot \mathrm{m}^{-2} ; \mathrm{n}=649$ ) Primary end-point: overall survival
Carboplatin/paclitaxel: 15\% Carboplatin/paclitaxel + bevacizumab: $35 \%(p<0.001)$

Cisplatin/gemcitabine: $20.1 \%$ Cisplatin/gemcitabine + bevacizumab $\left(7.5 \mathrm{mg} \cdot \mathrm{kg}^{-1}\right): 34.1 \%$ Cisplatin/gemcitabine + bevacizumab $\left(15 \mathrm{mg} \cdot \mathrm{kg}^{-1}\right)$ : $30.4 \%(p<0.0001$ and $p=0.0023$, respectively]

$$
p=0.0023 \text {, respectivelyl }
$$
Carboplatin/paclitaxel + cediranib: $38 \%$ $(p<0.0001)$

Carboplatin/paclitaxel: 34\% Carboplatin/paclitaxel + cediranib: $52 \%$ $(p=0.001)$

Carboplatin/paclitaxel: 27\% Carboplatin/paclitaxel + sorafenib: $24 \%$ ( $p=0.102)$
Gemcitabine/cisplatin: 26\% Gemcitabine/cisplatin + sorafenib: $28 \%$ ( $p=0.27)$

Carboplatin/paclitaxel: $26 \%$ Carboplatin/paclitaxel + motesanib: $40 \%(p<0.001)$

Carboplatin/paclitaxel: 25\% Carboplatin/paclitaxel + vadimezan: $25 \%(p=1.0$

$$
\begin{gathered}
\text { Carboplatin/paclitaxel: } \\
4.5 \text { months } \\
\text { Carboplatin/paclitaxel }+ \\
\text { bevacizumab: } 6.2 \text { months } \\
\text { HR } 0.66(95 \% \mathrm{Cl} 0.57-0.77) ; \\
p<0.001
\end{gathered}
$$

Cisplatin/gemcitabine: 6.1 months

Cisplatin/gemcitabine + bevacizumab $\left(7.5 \mathrm{mg} \cdot \mathrm{kg}^{-1}\right)$ : 6.7 months

Cisplatin/gemcitabine + bevacizumab $\left(15 \mathrm{mg} \cdot \mathrm{kg}^{-1}\right)$. 6.5 months HR 0.75 (95\% Cl 0.62-0.91): $\mathrm{p}=0.003$ and $\mathrm{HR} 0.92(95 \% \mathrm{Cl}$

$0.68-0.98) ; p=0.03$, respectively

\section{Carboplatin/paclitaxel: 5.0 months}

Carboplatin/paclitaxel +

cediranib: 5.6 months

HR 0.77 (95\% CI 0.56-1.08);

$$
p=0.13
$$

Carboplatin/paclitaxel: 5.5 months

Carboplatin/paclitaxel +

cediranib: 5.5 months

HR 0.91 (95\% Cl 0.71-1.18); $p=0.5$

Carboplatin/paclitaxel: 5.4 months

Carboplatin/paclitaxel +

sorafenib: 4.6 months

HR 0.99 (95\% Cl 0.84-1.16); $p=0.433$

Gemcitabine/cisplatin: 5.5 months

Gemcitabine/cisplatin +

sorafenib: 6.0 months HR 0.83 (95\% Cl 0.71-0.97): $p=0.008$

Carboplatin/paclitaxel: 5.4 months

Carboplatin/paclitaxel +

motesanib: 5.6 months HR 0.79 (95\% CI 0.61-0.98), $p<0.001$

$$
\begin{gathered}
\text { Carboplatin/paclitaxel: } \\
5.5 \text { months } \\
\text { Carboplatin/paclitaxel + } \\
\text { vadimezan: } 5.5 \text { months } \\
\text { HR } 1.04(95 \% \mathrm{Cl} 0.91-1.19) \text {; } \\
\mathrm{p}=0.727
\end{gathered}
$$

Carboplatin/paclitaxel: 10.3 months Carboplatin/paclitaxel + bevacizumab: 12.3 months HR 0.79 (95\% Cl 0.67-0.92); $p=0.003$

Cisplatin/gemcitabine: 13.1 months Cisplatin/gemcitabine + bevacizumab $\left(7.5 \mathrm{mg} \cdot \mathrm{kg}^{-1}\right): 13.6$ months

Cisplatin/gemcitabine + bevacizumab $\left(15 \mathrm{mg} \cdot \mathrm{kg}^{-1}\right): 13.4$ months HR 0.92 (95\% Cl 0.78-1.11); $p=0.420$ and HR 1.03 (95\% Cl 0.86-1.23); $p=0.761$, respectively

Carboplatin/paclitaxel: 10.1 months Carboplatin/paclitaxel + cediranib: 10.5 months

HR 0.78 (95\% Cl 0.57-1.06); $p=0.11$

Carboplatin/paclitaxel: 12.1 months Carboplatin/paclitaxel + cediranib: 12.2 months

HR 0.95 (95\% Cl 0.69-1.30); $p=0.74$

Carboplatin/paclitaxel: 10.6 months Carboplatin/paclitaxel + sorafenib: 10.7 months

HR 1.15 (95\% Cl 0.94-1.41); $p=0.915$

Gemcitabine/cisplatin: 12.5 months Gemcitabine/cisplatin + sorafenib: 12.4 months

HR 0.98 (65\% Cl 0.83-1.16); $p=0.401$

Carboplatin/paclitaxel: 11.0 months Carboplatin/paclitaxel + motesanib: 13.0 months

HR 0.90 (95\% Cl 0.78-1.04); $p=0.14$

Carboplatin/paclitaxel: 12.7 months Carboplatin/paclitaxel + vadimezan: 13.4 months

HR 1.01 (95\% Cl 0.85-1.19); $p=0.535$

ECOG: Eastern Cooperative Oncology Group; AVAiL: Avastin in Lung Cancer; TKI: tyrosine kinase inhibitor; ESCAPE: Evaluation of Sorafenib, Carboplatin and Paclitaxel Efficacy in NSCLC; NExUS: NSCLC research Experience Utilising Sorafenib; MONET1: Motesanib NSCLC Efficacy and Tolerability Study; ATTRACT-1: Antivascular Targeted Therapy: Researching ASA404 in Cancer Treatment; VEGF: vascular endothelial growth factor; VEGFR: VEGF receptor; PDGFR: platelet-derived growth factor receptor; FGFR: fibroblast growth factor receptor; RET: Rearranged during Transfection; NSCLC: nonsmall cell lung cancer; HR: hazard ratio. 
Based on these trials, bevacizumab was approved by the US Food and Drug Administration in 2006 and the European Medicines Agency in 2009 for first-line treatment of advanced NSCLC in combination with chemotherapy. It has been reported that bevacizumab may increase the risk of haemorrhage [31]. However, a recent phase IV study of 2212 patients with non-squamous NSCLC indicated that first-line bevacizumab plus chemotherapy has a manageable safety profile with a low incidence of grade $\geqslant 3$ bleeding events (4\%) [32].

Following the approval of bevacizumab for first-line treatment of non-squamous NSCLC, trials are ongoing to define its role in maintenance beyond progression and in adjuvant settings. In the ongoing ECOG 5508 trial, patients receiving induction therapy of carboplatin/paclitaxel/bevacizumab were randomised to receive maintenance therapy with bevacizumab, pemetrexed or bevacizumab plus pemetrexed [33]. The phase III AvaALL trial, with overall survival as its primary end-point, is currently randomising patients with advanced non-squamous NSCLC who have progressed following bevacizumab plus platinum-based chemotherapy to standard second-line therapy (pemetrexed, docetaxel or erlotinib) with or without bevacizumab [34].

The ECOG E1505 study is currently assessing the impact of adding bevacizumab to adjuvant chemotherapy in patients with completely resected stage IB-IIIA NSCLC [35].

\section{Recently completed randomised trials}

Following the approval of bevacizumab for the first-line treatment of non-squamous NSCLC, intense efforts are underway to develop other anti-VEGF agents (antibodies and small-molecule TKIs). However, recently reported phase III trials have failed to demonstrate a survival advantage compared with standard therapy (table 1) [23-27]. Some recently assessed TKIs and vascular disrupting agents are detailed below.

\section{Multi-targeted antiangiogenic orally administered TKIs}

Cediranib

Cediranib (Recentin; AstraZeneca, London, UK) is an orally administered TKI that inhibits VEGFR1-3, PDGFR- $\alpha / \beta$, FGFR1 and $c$-kit [36]. In a phase II/III trial $(n=251)$, interim analysis indicated a trend towards improved PFS in patients with advanced NSCLC treated with first-line cediranib (30 mg per day) plus carboplatin/paclitaxel versus chemotherapy alone (5.6 months versus 5.0 months; $\mathrm{p}=0.13$ ); however, the study was halted due to safety concerns [23]. In a subsequent phase III study, cediranib (20 mg per day) plus carboplatin/paclitaxel did not confer a survival advantage versus chemotherapy alone and increased toxicity; grade $>3$ hypertension $(15 \%$ versus $3 \%, p=0.0002)$, anorexia $(7 \%$ versus $1 \%, p=0.02)$ and diarrhoea $(16 \%$ versus $1 \%, \mathrm{p}<0.0001)$ were all significantly increased, hence the trial was halted [24].

\section{Sorafenib}

Sorafenib (Nexavar; Bayer, Pittsburgh, PA, USA) inhibits VEGFR2-3, PDGFR- $\beta$, c-kit, Raf and flt-3 [37]. A phase III trial (ESCAPE (Evaluation of Sorafenib, Carboplatin and Paclitaxel Efficacy in NSCLC); n=926) assessed sorafenib plus carboplatin/paclitaxel versus chemotherapy alone in patients with advanced untreated NSCLC [25]. There was no significant improvement in PFS (4.6 months versus 5.4 months; $\mathrm{p}=0.43)$ or overall survival $(10.7$ months versus 10.6 months; $\mathrm{p}=0.13)$. Furthermore, a high mortality rate was noted in patients with tumours showing a squamous histology. A second phase III trial (NExUS (NSCLC research Experience Utilising Sorafenib); $n=772$ ) showed a PFS improvement, but not an overall survival improvement, for sorafenib plus gemcitabine/cisplatin versus chemotherapy alone in a first-line setting [26].

\section{Motesanib}

Motesanib (Amgen, Thousand Oaks, CA, USA) inhibits VEGFR1-3, PDGFR, c-kit and RET [38]. A phase III trial (MONET1 (Motesanib NSCLC Efficacy and Tolerability Study); $\mathrm{n}=1090$ ) assessed motesanib plus carboplatin/paclitaxel versus chemotherapy alone in advanced non-squamous NSCLC. Motesanib conferred significant improvements in PFS $(5.6$ months versus 5.4 months; $\mathrm{p}<0.001)$ and response rate $(40 \%$ versus $26 \% ; \mathrm{p}<0.001)$, but there was no significant improvement in the primary end-point, overall survival (13.0 months versus 11.0 months; $\mathrm{p}=0.14$ ) [27]. Moreover, the incidence of grade $\geqslant 3$ adverse events $(73 \%$ versus 59\%) and grade 5 adverse events (14\% versus 9\%) were higher with motesanib treatment.

\section{Axitinib}

Axitinib (Inlyta; Pfizer) inhibits VEGFR1-3, PDGFR- $\beta$ and c-kit [39]. An initial single-arm phase II study $(\mathrm{n}=32)$ assessed the single-agent axitinib in patients with NSCLC (first and second line). The results of this study were promising, with a reported disease control rate (partial response plus stable disease) of $41 \%$, median PFS of 4.9 months and median overall survival of 14.8 months [40]. However, subsequent phase II clinical trial results have been disappointing. In a randomised study, axitinib plus carboplatin/paclitaxel did 
not improve PFS or overall survival versus bevacizumab plus carboplatin/paclitaxel [41]. In another study, axitinib plus pemetrexed/cisplatin did not improve overall survival or PFS versus chemotherapy alone [42].

\section{Vascular disrupting agents}

Vadimezan

Vadimezan is a fused tricyclic analogue of flavone acetic acid that acts as a vascular disrupting agent. In contrast to antiangiogenic agents that inhibit proliferation of new blood vessels, vadimezan induces an acute and largely irreversible collapse in existing tumour vascular supply [43]. In a phase III trial (ATTRACT-1 (Antivascular Targeted Therapy: Researching ASA404 in Cancer Treatment); $n=1299$ ) the addition of intravenous vadimezan to carboplatin/paclitaxel chemotherapy failed to improve either overall survival (13.4 months versus 12.7 months; $\mathrm{p}=0.54$ ) or PFS (5.5 versus 5.5 months; $\mathrm{p}=0.73$ ) in patients with advanced stage IIIB/IV NSCLC [28]. Grade 4 neutropenia (27\% versus $19 \%)$ and infusion site pain (10\% versus $0.5 \%$ ) were reported more frequently in the ASA404 arm.

\section{Antiangiogenic agents in a relapsed/refractory setting}

\section{Recently completed randomised trials}

There is a major unmet need for new treatment options in patients with relapsed/refractory NSCLC. Unfortunately, to date, no antiangiogenic agents have been approved for the treatment of relapsed/ refractory NSCLC. The results from the majority of phase III trials that have assessed antiangiogenic agents in a second-line setting have been disappointing (table 2) [44-53]. However, there has been recent progress with agents that simultaneously target multiple signalling pathways.

\section{Multi-targeted antiangiogenic orally administered TKIs}

Nintedanib

Nintedanib is an orally administered, small-molecule triple angiokinase inhibitor of VEGF1-3, PDGF- $\alpha$ and $\beta$, and FGFR1-3 that has demonstrated substantial anti-tumour and antiangiogenic activity in pre-clinical experiments [54, 55] and in clinical phase I/II trials in patients with NSCLC [56-58]. Nintedanib is the first antiangiogenic agent to demonstrate a survival benefit in the second-line treatment of patients with adenocarcinoma NSCLC versus an active comparator [44].

Two independent, multicentre, phase III studies have assessed nintedanib combined with either docetaxel or pemetrexed in patients with advanced or recurrent NSCLC for whom first-line chemotherapy had failed (table 2). The LUME-Lung 1 study $(\mathrm{n}=1314)$ assessed nintedanib (200 mg twice daily; day 2-21) plus docetaxel $\left(75 \mathrm{mg} \cdot \mathrm{m}^{-2}\right.$ every 21 days) versus docetaxel alone in patients with stage III/IV or recurrent NSCLC with any histology [44]. Nintedanib plus docetaxel significantly improved PFS versus docetaxel alone regardless of histology (HR 0.79, 95\% CI 0.68-92; 3.4 months versus 2.7 months; $p=0.002$ ). In the hierarchical testing for the key secondary end-point, overall survival, there was a significant improvement in patients with adenocarcinoma (HR 0.83, 95\% CI 0.70-99; 12.6 months versus 10.3 months; $\mathrm{p}=0.036$ ) with the greatest improvement observed in patients who started nintedanib $<9$ months after initiation of firstline therapy (HR 0.75, 95\% CI 0.60-92; 10.9 months versus 7.9 months; $\mathrm{p}=0.036$ ). In addition, there was a trend towards increased overall survival in all histologies (10.1 months versus 9.1 months; $\mathrm{p}=0.272)$. Incidence of grade $\geqslant 3$ adverse events was $71.3 \%$ versus $64.3 \%$. The most common adverse events were diarrhoea $(42.3 \%$ versus $21.8 \%)$ and reversible alanine aminotransferase elevations $(28.5 \%$ versus $8.4 \%)$. LUME-Lung 2 ( $\mathrm{n}=713$ ) assessed nintedanib (200 $\mathrm{mg}$ twice daily; day 2-21) plus pemetrexed $\left(500 \mathrm{mg} \cdot \mathrm{m}^{-2}\right.$ every 21 days) versus pemetrexed alone in patients with non-squamous NSCLC [45]. In this study, recruitment was halted early based on a pre-planned futility analysis of investigator-assessed PFS by an independent data monitoring committee. The data monitoring committee concluded that the likelihood of meeting the primary end-point (centrally reviewed PFS) was low, although no safety concerns were raised. Following the futility analysis, patients were unblinded and followed up per protocol. Interestingly, subsequent analysis $(n=713$; planned enrolment was $n=1111)$ demonstrated that the primary end-point of centrally reviewed PFS was met even though the study was stopped prematurely. Nintedanib plus pemetrexed significantly improved PFS (HR 0.83, 95\% CI 0.70-99; 4.4 months versus 3.6 months; $\mathrm{p}=0.04$ ), but not overall survival, versus pemetrexed alone. Notably, the incidence of grade $\geqslant 3$ hypertension, bleeding and thromboembolism was similar between treatment arms [44, 45].

\section{Vandetanib}

Vandetanib (Zactima; AstraZeneca) is an orally administered TKI that inhibits VEGFR2 and 3, RET and EGFR [59]. Based on a large phase III programme comprising four randomised trials in patients with advanced disease, development of vandetanib in NSCLC has been discontinued. The ZODIAC (Zactima in Combination with Docetaxel in NSCLC) trial assessed second-line docetaxel plus vandetanib versus 


\section{TABLE 2 Recent phase III trials assessing antiangiogenic agents in a second- or third-line setting}

\begin{tabular}{|c|c|c|c|c|c|}
\hline Agent and study name [ref.] & Target (s) & Study design & Overall response rate & Progression-free survival & Overall survival \\
\hline \multicolumn{6}{|l|}{$\begin{array}{l}\text { Multi-targeted antiangiogenic } \\
\text { orally administered TKIs }\end{array}$} \\
\hline Nintedanib; LUME-Lung 1[44] & $\begin{array}{l}\text { VEGF-1-3, PDGF- } \alpha \\
\text { and } \beta \text {, and FGFR-1-3 }\end{array}$ & $\begin{array}{c}\text { Stage IIIB/IV NSCLC all } \\
\text { histologies } \\
\text { Patients randomised to: docetaxel } \\
\text { (n=659) or docetaxel }+ \text { nintedanib } \\
\text { (200 mg twice daily; } n=655) \\
\text { Primary end-point: progression- } \\
\text { free survival }\end{array}$ & $\begin{array}{l}\text { Overall response rate not } \\
\text { reported } \\
\text { DCR was significantly greater in } \\
\text { the docetaxel + nintedanib arm } \\
\text { in patients with adenocarcinoma } \\
\qquad(p<0.0001)\end{array}$ & $\begin{array}{c}\text { Docetaxel: } 2.7 \text { months } \\
\text { Docetaxel + nintedanib: } \\
3.4 \text { months } \\
\text { HR } 0.79 \text { (Cl } 0.68-0.92 \text { ); } \mathrm{p}=0.002\end{array}$ & $\begin{array}{c}\text { In patients with adenocarcinoma: } \\
\text { Docetaxel: } 10.3 \text { months } \\
\text { Docetaxel + nintedanib: } 12.6 \text { months } \\
\text { HR } 0.83 ; \mathrm{p}=0.036 \\
\text { In overall population: } \\
\text { Docetaxel: } 9.1 \text { months } \\
\text { Docetaxel + nintedanib: } 10.1 \text { months } \\
\text { HR } 0.94 ; \mathrm{p}=0.272\end{array}$ \\
\hline Nintedanib; LUME-Lung 2 [45] & $\begin{array}{l}\text { VEGF-1-3, PDGF- } \alpha \\
\text { and } \beta \text {, and FGFR-1-3 }\end{array}$ & $\begin{array}{l}\text { Stage IIIB/IV non-squamous } \\
\text { NSCLC } \\
\text { Patients randomised to: peme- } \\
\text { trexed ( } n=360 \text { ) or pemetrexed }+ \\
\text { nintedanib (200 mg twice daily; } \\
\quad n=353 \text { ) } \\
\text { Primary end-point: progression- } \\
\text { free survival }\end{array}$ & $\begin{array}{c}\text { No difference in overall } \\
\text { response rate between peme- } \\
\text { trexed and pemetrexed + } \\
\text { nintedanib }(9 \%) \\
\text { Pemetrexed: DCR } 53 \% \\
\text { Pemetrexed + nintedanib: DCR } \\
61 \% \\
{[p=0.039]}\end{array}$ & $\begin{array}{c}\text { Pemetrexed: } 3.6 \text { months } \\
\text { Pemetrexed + nintedanib: } \\
4.4 \text { months } \\
\text { HR } 0.83(95 \% \mathrm{Cl} 0.7-0.99) ; \mathrm{p}=0.04\end{array}$ & $\begin{array}{c}\text { No significant difference (median } \\
\text { values NR) }\end{array}$ \\
\hline Vandetanib; ZODIAC [46] & $\begin{array}{l}\text { VEGFR-1 and }-2, \text { RET } \\
\text { and EGFR }\end{array}$ & $\begin{array}{c}\text { Stage IIIB/IV NSCLC all } \\
\text { histologies } \\
\text { Patients randomised to: docetaxel } \\
\text { (n=697) or docetaxel + vandetanib } \\
\left(100 \mathrm{mg} \cdot \text { day }^{-1} ; \mathrm{n}=694\right) \\
\text { Primary end-point: progression- } \\
\text { free survival }\end{array}$ & $\begin{array}{c}\text { Docetaxel: } 10 \% \\
\text { Docetaxel + vandetanib: } 17 \% \\
\text { ( } p=0.0001)\end{array}$ & $\begin{array}{c}\text { Docetaxel: } 3.2 \text { months } \\
\text { Docetaxel + vandetanib: } \\
4.0 \text { months } \\
\text { HR } 0.79(97.6 \% \mathrm{Cl} 0.70-0.90) \\
\mathrm{p}<0.0001\end{array}$ & $\begin{array}{l}\text { Docetaxel: } 10.0 \text { months } \\
\text { Docetaxel + vandetanib: } 10.6 \text { months } \\
\text { HR } 0.91(97.5 \% \mathrm{Cl} 0.78-1.07) ; p=0.196\end{array}$ \\
\hline Vandetanib; ZEAL [47] & $\begin{array}{l}\text { VEGFR-1 and }-2, \text { RET } \\
\text { and EGFR }\end{array}$ & $\begin{array}{c}\text { Stage IIIB/IV NSCLC all } \\
\text { histologies } \\
\text { Patients randomised to: peme- } \\
\text { trexed ( } \mathrm{n}=278 \text { ) or pemetrexed }+ \\
\text { vandetanib (100 mg } \cdot \text { day }^{-1} ; \mathrm{n}=256 \text { ) } \\
\text { Primary end-point: progression- } \\
\text { free survival }\end{array}$ & $\begin{array}{c}\text { Pemetrexed: } 8 \% \\
\text { Pemetrexed + vandetanib: } 19 \% \\
\text { ( } p<0.001)\end{array}$ & $\begin{array}{c}\text { Pemetrexed: } 11.9 \text { weeks } \\
\text { Pemetrexed + vandetanib: } \\
17.6 \text { weeks } \\
\text { HR 0.86 }(97.6 \% \mathrm{Cl} 0.69-1.06) ; \\
p=0.108\end{array}$ & $\begin{array}{c}\text { Pemetrexed: } 9.2 \text { months } \\
\text { Pemetrexed + vandetanib: } \\
10.5 \text { months } \\
\text { HR } 0.86(97.5 \% \mathrm{Cl} 0.65-1.13) ; \\
p=0.219\end{array}$ \\
\hline Vandetanib; ZEPHYR [48] & $\begin{array}{l}\text { VEGFR-1 and }-2, \text { RET } \\
\text { and EGFR }\end{array}$ & $\begin{array}{c}\text { Stage IIIB/IV NSCLC all } \\
\text { histologies } \\
\text { Pre-treated with EGFR inhibitor } \\
\text { and one or two chemotherapy } \\
\text { regimens } \\
\text { Patients randomised to: placebo } \\
\text { ( } \mathrm{n}=307) \text { or vandetanib } \\
\left(300 \mathrm{mg}^{-1} \text { day }{ }^{-1} ; \mathrm{n}=617\right) \\
\text { Primary end-point: overall } \\
\text { survival }\end{array}$ & $\begin{array}{l}\text { Placebo: } 0.7 \% \\
\text { Vandetanib: } 2.6 \% \\
\quad(p=0.028)\end{array}$ & $\begin{array}{c}\text { Placebo: } 1.8 \text { months } \\
\text { Vandetanib: } 1.9 \text { months } \\
\text { HR } 0.63(95.2 \% \text { Cl } 0.54-0.74) \\
p<0.001\end{array}$ & $\begin{array}{c}\text { Placebo: } 7.8 \text { months } \\
\text { Vandetanib: } 8.5 \text { months } \\
\text { HR } 0.95(95.2 \% \mathrm{Cl} 0.81-1.11) ; p=0.527\end{array}$ \\
\hline Vandetanib; ZEST [49] & $\begin{array}{l}\text { VEGFR-1 and }-2, \text { RET } \\
\text { and EGFR }\end{array}$ & $\begin{array}{l}\text { Stage IIIB/IV NSCLC all } \\
\text { histologies } \\
\text { Patients randomised to: erlotinib } \\
\left(150 \mathrm{mg} \cdot \text { day }^{-1} ; \mathrm{n}=617\right) \text { or vande- } \\
\text { tanib }\left(300 \mathrm{mg} \cdot \text { day }^{-1} ; \mathrm{n}=623\right) \\
\text { Primary end-point: progression- } \\
\text { free survival }\end{array}$ & $\begin{array}{l}\text { Erlotinib: } 12 \% \\
\text { Vandetanib: } 12 \% \\
\quad(p=0.98)\end{array}$ & $\begin{array}{c}\text { Erlotinib: } 2.0 \text { months } \\
\text { Vandetanib: } 2.6 \text { months } \\
\text { HR 0.98 (95.2\% Cl } 0.87-1.10) \text {; } \\
p=0.721\end{array}$ & $\begin{array}{c}\text { Erlotinib: } 7.8 \text { months } \\
\text { Vandetanib: } 6.9 \text { months } \\
\text { HR } 1.01(95.1 \% \mathrm{Cl} 0.89-1.16) ; \mathrm{p}=0.830\end{array}$ \\
\hline Sorafenib; MISSION [50] & $\begin{array}{l}\text { VEGFR-2-3, PDGFR- } \beta \text {, } \\
\text { c-kit, Raf and flt-3 }\end{array}$ & $\begin{array}{c}\text { Stage IIIB/IV non-squamous } \\
\text { NSCLC } \\
\text { Patients randomised to: placebo } \\
\text { ( } \mathrm{n}=353 \text { ) or sorafenib ( } 400 \mathrm{mg} \\
\text { twice daily; } \mathrm{n}=350 \text { ) } \\
\text { Primary end-point: overall } \\
\text { survival }\end{array}$ & $\begin{array}{l}\text { Placebo: } 0.9 \% \\
\text { Sorafenib: } 4.9 \% \\
\quad(p<0.001)\end{array}$ & $\begin{array}{l}\text { Placebo: } 43 \text { days } \\
\text { Sorafenib: } 84 \text { days } \\
\text { HR } 0.61 ; p<0.0001\end{array}$ & $\begin{array}{l}\text { Placebo: } 253 \text { days } \\
\text { Sorafenib: } 248 \text { days } \\
\text { HR } 0.99 ; \mathrm{p}=0.4687\end{array}$ \\
\hline Sunitinib [51] & $\begin{array}{l}\text { VEGF-1-3, PDGFR- } \alpha \\
\text { and } \beta \text {, and RET }\end{array}$ & 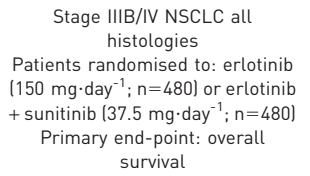 & $\begin{array}{l}\text { Erlotinib: } 6.9 \% \\
\text { Erlotinib + sunitinib: } 10.6 \% \\
\quad(p=0.048)\end{array}$ & $\begin{array}{c}\text { Erlotinib: } 2.0 \text { months } \\
\text { Erlotinib + sunitinib: } 3.6 \text { months } \\
\text { HR } 0.81(95 \% \mathrm{Cl} 0.70-0.94) ; \\
p=0.0023\end{array}$ & $\begin{array}{c}\text { Erlotinib: } 8.5 \text { months } \\
\text { Erlotinib + sunitinib: } 9.0 \text { months } \\
\text { HR } 0.92(95 \% \mathrm{Cl} 0.80-1.07) ; p=0.139\end{array}$ \\
\hline \multicolumn{6}{|l|}{$\begin{array}{l}\text { Monoclonal antibodies, decoy } \\
\text { receptors }\end{array}$} \\
\hline Bevacizumab; BeTa [52] & VEGF & $\begin{array}{c}\text { Stage IIIB/IV NSCLC all } \\
\text { histologies } \\
\text { Patients randomised to: erlotinib } \\
\left.\text { (150 mg } \cdot \text { day }{ }^{-1} ; n=317\right) \text { or erlotinib } \\
+ \text { bevacizumab }(n=319) \\
\text { Primary end-point: progression- } \\
\text { free survival }\end{array}$ & $\begin{array}{c}\text { Erlotinib: } 6 \% \\
\text { Erlotinib + bevacizumab: } 13 \% \\
\text { (p-value NR) }\end{array}$ & $\begin{array}{c}\text { Erlotinib: } 1.7 \text { months } \\
\text { Erlotinib }+ \text { bevacizumab: } \\
3.4 \text { months } \\
\text { HR } 0.62(95 \% \mathrm{Cl} 0.52-0.75) ; \\
\text { p-value NR }\end{array}$ & $\begin{array}{l}\text { Erlotinib: } 9.2 \text { months } \\
\text { Erlotinib + bevacizumab: } 9.3 \text { months } \\
\text { HR } 0.97 \text { ( } 95 \% \mathrm{Cl} 0.80-1.18 \text { ); } p=0.758\end{array}$ \\
\hline Aflibercept; VITAL [53] & VEGF & $\begin{array}{c}\text { Non-squamous NSCLC } \\
\text { Patients randomised to: docetaxel } \\
\text { ( } \mathrm{n}=457) \text { or docetaxel }+ \text { aflibercept } \\
\left(6 \mathrm{mg} \cdot \text { day }^{-1} ; \mathrm{n}=456\right) \\
\text { Primary end-point: overall } \\
\text { survival }\end{array}$ & $\begin{array}{c}\text { Docetaxel: } 8.9 \% \\
\text { Docetaxel + aflibercept: } 23.3 \% \\
(p<0.001)\end{array}$ & $\begin{array}{c}\text { Docetaxel: } 4.1 \text { months } \\
\text { Docetaxel + aflibercept: } \\
5.2 \text { months } \\
\text { HR } 0.82(95 \% \mathrm{Cl} 0.72-0.94) ; \\
p=0.0035\end{array}$ & $\begin{array}{l}\text { Docetaxel: } 10.4 \text { months } \\
\text { Docetaxel + aflibercept: } 10.1 \text { months } \\
\text { HR } 1.01(95 \% \text { Cl } 0.87-1.17) ; p=0.9\end{array}$ \\
\hline
\end{tabular}

TKI: tyrosine kinase inhibitor; ZODIAC: Zactima in Combination with Docetaxel in NSCLC; ZEAL : Zactima Efficacy with Alimta in Lung Cancer; ZEPHYR: Zactima Efficacy Trial for NSCLC Patients with a History of EGFR-TKI and Chemoresistance; ZEST: Zactima Efficacy Study versus Tarceva; VEGF: vascular endothelial growth factor; PDGF: platelet-derived growth factor; FGFR: fibroblast growth factor receptor; VEGFR: VEGF receptor; EGFR: epidermal growth factor receptor; PDGFR: PDGF receptor; NSCLC: nonsmall cell lung cancer; NR: not reported; DCR: disease control rate; HR: hazard ratio. 
docetaxel alone [46]. A significant improvement in median PFS was observed in the combination arm (HR $0.83,95 \%$ CI $0.70-99 ; 4.0$ months versus 3.2 months; $\mathrm{p}<0.0001)$, but there was no significant improvement in overall survival (HR 0.91, 97.5\% CI 0.78-1.07; 10.6 months versus 10.0 months; $\mathrm{p}=0.196$ ). The ZEAL (Zactima Efficacy with Alimta in Lung Cancer) trial assessed second-line pemetrexed plus vandetanib versus pemetrexed alone [47]. In this trial there was no significant improvement in either PFS (HR 0.86, 95\% CI $0.69-1.06 ; 17.6$ weeks versus 11.9 weeks; $\mathrm{p}=0.108)$ or overall survival (HR 0.86, 95\% CI $0.65-1.13$; 10.5 months versus 9.2 months; $\mathrm{p}=0.219$ ). Similarly, in the ZEST (Zactima Efficacy Study versus Tarceva) trial, the use of vandetanib instead of erlotinib did not confer any survival advantage [49]. Vandetanib was also assessed in a third-line setting in the ZEPHYR (Zactima Efficacy Trial for NSCLC Patients with a History of EGFR-TKI and Chemoresistance) trial [48]. In this study, vandetanib conferred a small but significant improvement in PFS (HR 0.63, 95\% CI 0.54-0.74; 1.9 months versus 1.8 months; $\mathrm{p}<0.001$ ), but no improvement in overall survival versus placebo (HR 0.95, 95\% CI 0.81-1.11; 8.5 months versus 7.8 months; $\mathrm{p}=0.527$ ). The adverse event profile of vandetanib was consistent across studies; rates of diarrhoea, rash and hypertension were higher than observed in control arms.

\section{Sorafenib}

A recent phase III study assessed third-line sorafenib monotherapy versus placebo in patients with nonsquamous NSCLC (the MISSION trial) [50]. Sorafenib conferred a significant improvement in median PFS (HR 0.61; 84 days versus 43 days; $\mathrm{p}<0.0001$ ), but not overall survival, versus placebo (HR 0.99; 248 days versus 253 days; $\mathrm{p}=0.469)$. Rates of all $(99 \%$ versus $91 \%)$ and serious adverse events $(39 \%$ versus $32 \%)$ were higher in the sorafenib group. A phase II trial has assessed sorafenib plus pemetrexed in a second-line setting in a phase II trial with disappointing results [60]. Neither overall survival nor PFS were improved in patients given sorafenib plus pemetrexed versus pemetrexed alone, although post hoc analysis suggested a marginal PFS benefit with the combination in patients who had previously received bevacizumab.

\section{Sunitinib}

Sunitinib (Sutent; Pfizer) is a TKI that inhibits VEGF1-3, PDGFR- $\alpha$ and $\beta$, and RET [61]. A recent phase III study assessed second-line sunitinib plus erlotinib versus erlotinib alone in patients with advanced NSCLC [51]. Median PFS (HR 0.81, 95\% CI 0.70-0.94; 3.6 months versus 2.0 months; $\mathrm{p}=0.0023$ ) but not median overall survival (HR 0.92, 95\% CI 0.80-1.07; 9.0 months versus 8.5 months; $\mathrm{p}=0.139$ ) was significantly improved in the sunitinib plus erlotinib arm versus erlotinib alone. Grade $\geqslant 3$ treatment related adverse events that were more common in the sunitinib arm included rash/dermatitis (17.4\% versus $9.6 \%$ ), diarrhoea (15.8\% versus $2.9 \%)$ and asthenia/fatigue (8.0\% versus $3.3 \%)$. A phase II study demonstrated that the addition of sunitinib to pemetrexed did not improve survival outcomes versus pemetrexed alone; indeed, sunitinib had a detrimental impact on overall survival and tolerability [62].

\section{Monoclonal antibodies/decoy receptors}

Bevacizumab

A recent phase III study assessed bevacizumab with or without erlotinib in a second-line setting [52]. Although median PFS was greater in the bevacizumab arm (HR 0.62, 95\% CI 0.52-0.75; 3.4 months versus 1.7 months), the trial did not achieve its primary end-point of improved median overall survival (HR 0.97, 95\% CI $0.80-1.18$; 9.3 months versus 9.2 months). In the bevacizumab arm, $42 \%$ of patients had a serious adverse event compared with $36 \%$ of controls. There were $20(6 \%)$ grade 5 adverse events, including two arterial thromboembolic events in the bevacizumab arm, and $14(4 \%)$ in the control arm. Ongoing studies are assessing the feasibility of combining bevacizumab with pemetrexed or docetaxel in a second-line setting.

\section{Aflibercept}

Disappointing results have also been obtained with agents other than TKIs. Aflibercept is a novel recombinant protein designed to act as soluble decoy receptor for VEGF, thus preventing it from binding to its receptors. A recent phase III trial assessed aflibercept plus docetaxel versus docetaxel alone in 913 patients with advanced NSCLC who had progressed following first-line chemotherapy [53]. Aflibercept improved median PFS (HR 0.82, 95\% CI 0.72-0.94; 5.2 months versus 4.1 months; $\mathrm{p}=0.004$ ) but not median overall survival (HR 1.01, 95\% CI 0.87-1.17; 10.1 months versus 10.4 months; $\mathrm{p}=0.9$ ) and it was associated with increased adverse events. Grade $\geqslant 3$ adverse events that occurred more frequently in the aflibercept arm versus the placebo arm were neutropenia ( $28 \%$ versus $21 \%)$, fatigue ( $11 \%$ versus $4 \%$ ), stomatitis ( $9 \%$ versus $<1 \%)$ and hypertension $(7 \%$ versus $<1 \%)$. 
Vascular disrupting agents

Vadimezan

A phase III trial assessed docetaxel with or without vadimezan in a second-line setting in patients with advanced NSCLC; the trial was terminated based on an interim analysis that showed no increase in overall survival benefit [63].

\section{Other investigational antiangiogenic agents in NSCLC}

Despite recent failures, the major unmet clinical need for additional treatment in NSCLC continues to drive the clinical development of novel antiangiogenic agents in both first-line and relapsed/refractory settings. Several agents currently being assessed in clinical trials are described below.

\section{Ramucirumab}

Ramucirumab is a monoclonal antibody that specifically binds VEGFR2 [64]. Preliminary data from a phase II trial that assessed ramucirumab plus carboplatin/paclitaxel in a first-line setting were encouraging, with a $67 \%$ response rate reported [65]. In this study, two patients reported serious adverse events possibly related to ramucirumab: grade 4 febrile neutropenia and grade 2 pneumothorax. Another phase II trial to assess ramucirumab in a first-line setting in combination with four different chemotherapy regimens is currently recruiting patients [66]. In addition, the ongoing phase III trial REVEL (Randomized Evaluation of the Effects of Anacetrapib Through Lipid-modification) is assessing ramucirumab plus docetaxel versus docetaxel alone in patients who have progressed following platinum chemotherapy [67].

\section{Cediranib}

Cediranib in combination with pemetrexed has recently been assessed in a phase II trial of patients with relapsed/refractory NSCLC (who may or may not have been treated with bevacizumab). A promising response rate of 35\%, PFS of 5.6 months and overall survival of 11.5 months was observed in patients with non-squamous histology [68]. Grade 3/4 toxicities included neutropenia (14\%), febrile neutropenia (5\%), fatigue (22\%), diarrhoea (14\%) and infection (8\%). One patient each developed a pulmonary haemorrhage, cardiac ischaemia and a cerebrovascular event.

Pazopanib

Pazopanib (Votrient; GlaxoSmithKline) is a TKI with activity against VEGFR1-3, PDGFR- $\alpha / \beta$ and c-kit [69]. A number of phase II trials are ongoing in patients with NSCLC including: first-line therapy plus paclitaxel, second-line therapy plus pemetrexed and maintenance therapy [70-72]. An early clinical trial demonstrated that pazopanib (800 $\mathrm{mg}$ per day) plus pemetrexed had preliminary activity in patients with advanced NSCLC [73]. The most common adverse events included fatigue, neutropenia, diarrhoea and thrombocytopenia. The rates of all grade and grade 4 haematological toxicities were higher with the combination regimen than with either monotherapy. A phase III trial assessed pazopanib monotherapy (800 mg per day) in patients with resectable stage I/II NSCLC $(n=35)$ [74]. Three partial responses $(8.6 \%)$ and 30 cases of stable disease $(88.6 \%)$ were observed.

\section{Linifanib}

Linifanib is a TKI that inhibits VEGFR1-3, PDGFR- $\beta$, c-Kit and FLT-3 [75]. A phase II study assessed linifanib monotherapy (two dose regimens) in a second-/third-line setting in 139 patients with advanced NSCLC; linifanib displayed modest clinical activity with an overall response rate of 5\%, PFS of 3.6 months and overall survival of 9.0 months [76]. In this study, the most common linifanib-related adverse events were fatigue $(42 \%)$, decreased appetite (38\%), hypertension (37\%), diarrhoea (32\%), nausea (27\%), palmar-plantar erythrodysesthesia $(24 \%)$ and proteinuria $(22 \%)$. These events were more common in the high-dose group. The most common linifanib-related grade 3 or 4 adverse event was hypertension (14\%).

Another phase II study assessed paclitaxel/carboplatin with or without linifanib (7.5 mg or $12.5 \mathrm{mg})$ in previously untreated patients with advanced non-squamous NSCLC [77]. The addition of linifanib to chemotherapy was tolerable at the doses tested and resulted in a significant improvement in PFS (7.5 mg group: 8.3 months versus 5.4 months, $\mathrm{p}=0.022$ ) and a modest trend towards survival improvement in the $12.5 \mathrm{mg}$ group (13.0 months versus 11.3 months; $\mathrm{p}=$ nonsignificant) versus placebo.

\section{Outlook for antiangiogenic therapy in NSCLC}

Some antiangiogenic agents have demonstrated efficacy in clinical trials. The approval of bevacizumab in combination with platinum chemotherapy has shown that antiangiogenic agents can improve outcomes in a first-line setting. Moreover, recent data indicate that nintedanib, a triple kinase inhibitor, can improve survival when added to docetaxel as a second-line treatment of patients with lung adenocarcinoma [44, 45]. 
To date, no other antiangiogenic agents have emerged to supplement the current armamentarium available for patients with advanced NSCLC, although several are in development. Thus, there remains a substantial requirement to identify new treatment options for these patients.

Given the biological rationale for targeting angiogenesis, and the clinical precedent of bevacizumab, why has there been such a high failure rate of trials that have assessed antiangiogenic agents in NSCLC? There are several possible explanations for this observation. First, agents may not effectively combat the redundancy of angiogenic pathways. Owing to the structural similarities of tyrosine kinases most small-molecule TKIs have inhibitory activity over a range of receptors. However, other than nintedanib, no agents with inhibitory potency over all subtypes of VEGFR, PDGFR and FGFR have been tested in a phase III trial. Secondly, the TKIs tested to date may not completely inhibit signalling via their target receptors [9]. It is possible that agents with more favourable pharmacological profiles may be effective at completely abrogating, rather than downregulating, signalling via proangiogenic pathways. Finally, owing to the highly heterogeneous nature of NSCLC, it is probable that certain patients are more likely to respond to antiangiogenic agents than others. In several diseases, validated biomarkers have been identified for specific subgroups of patients who have a high probability of responding to a particular agent. Clinical experience with EGFR inhibitors suggests that antiangiogenic agents will be most effective against tumours with specific molecular characteristics. In recent years, significant progress has been made in identifying disease variants according to histological subtype or genetic characterisation of tumours $[78,79]$. Drugs have been identified that work effectively in a subset of patients defined by genetic variants, e.g. afatinib, erlotinib and gefitinib in patients with activating EGFR mutations. Biomarkers are urgently required for antiangiogenic agents and are a focus of intensive research.

Another important consideration for the development and application of antiangiogenic agents in NSCLC is their characteristic adverse event profiles [80]. Generally, targeted agents are much better tolerated than chemotherapy and are associated with lower incidences of cytopenia. However, most antiangiogenic agents may be associated with class-specific adverse events such as hypertension, haemorrhage or venous thromboembolism. The risk of such events may preclude treatment in some patients. Therefore, it is important that accumulated safety data are considered for emerging agents and factors that predict the risk of adverse events are identified.

\section{Conclusions}

Available treatment options for advanced NSCLC have limited efficacy, with few advances in clinical trials over the past decade leaving a substantial unmet medical need for new treatment options. There is a biological and clinical rationale for targeting angiogenesis in patients with advanced NSCLC, as demonstrated by the approval of bevacizumab and recent encouraging phase III data with nintedanib. Future priorities for the development of antiangiogenic agents in NSCLC include the development of drugs that effectively and potently inhibit a network of proangiogenic signals. Further biological studies are required to understand the pathogenesis of NSCLC in order to facilitate the identification of prognostic and predictive biomarkers that could be routinely applied in clinical practice.

\section{Acknowledgements}

We received medical writing assistance from L. Pritchard (GeoMed, Macclesfield, UK), supported by Boehringer Ingelheim, Germany.

\section{References}

1 American Cancer Society. Non-small cell lung cancer survival rates by stage. www.cancer.org/cancer/lungcancernon-smallcell/detailedguide/non-small-cell-lung-cancer-survival-rates Date last updated: July 12, 2013. Date last accessed: October 2013.

2 Peters S, Adjei AA, Gridelli C, et al. Metastatic non-small-cell lung cancer (NSCLC): ESMO Clinical Practice Guidelines for diagnosis, treatment and follow-up. Ann Oncol 2012; 23: Suppl. 7, vii56-vii64.

3 Sculier JP, Moro-Sibilot D. First- and second-line therapy for advanced nonsmall cell lung cancer. Eur Respir J 2009; 33: 915-930.

4 Oxnard GR, Arcila ME, Chmielecki J, et al. New strategies in overcoming acquired resistance to epidermal growth factor receptor tyrosine kinase inhibitors in lung cancer. Clin Cancer Res 2011; 17: 5530-5537.

5 Shepherd FA, Dancey J, Ramlau R, et al. Prospective randomized trial of docetaxel versus best supportive care in patients with non-small-cell lung cancer previously treated with platinum-based chemotherapy. J Clin Oncol 2000; 18: 2095-2103.

6 Hanna N, Shepherd FA, Fossella FV, et al. Randomized phase III trial of pemetrexed versus docetaxel in patients with non-small-cell lung cancer previously treated with chemotherapy. J Clin Oncol 2004; 22: 1589-1597.

7 Shepherd FA, Rodrigues PJ, Ciuleanu T, et al. Erlotinib in previously treated non-small-cell lung cancer. $N$ Engl $J$ Med 2005; 353: 123-132.

8 Hensing TA, Schell MJ, Lee JH, et al. Factors associated with the likelihood of receiving second line therapy for advanced non-small cell lung cancer. Lung Cancer 2005; 47: 253-259. 
Aggarwal C, Somaiah N, Simon G. Antiangiogenic agents in the management of non-small cell lung cancer: where do we stand now and where are we headed? Cancer Biol Ther 2012; 13: 247-263.

10 Ferrara N, Kerbel RS. Angiogenesis as a therapeutic target. Nature 2005; 438: 967-974.

11 De Bock K, Mazzone M, Carmeliet P. Antiangiogenic therapy, hypoxia, and metastasis: risky liaisons, or not? Nat Rev Clin Oncol 2011; 8: 393-404.

12 Hicklin DJ, Ellis LM. Role of the vascular endothelial growth factor pathway in tumor growth and angiogenesis. J Clin Oncol 2005; 23: 1011-1027.

13 Imai K, Takaoka A. Comparing antibody and small-molecule therapies for cancer. Nat Rev Cancer 2006; 6: 714-727.

14 Sandler A, Gray R, Perry MC, et al. Paclitaxel-carboplatin alone or with bevacizumab for non-small-cell lung cancer. N Engl J Med 2006; 355: 2542-2550.

15 Ballas MS, Chachoua A. Rationale for targeting VEGF, FGF, and PDGF for the treatment of NSCLC. Onco Targets Ther 2011; 4: 43-58.

16 Presta M, Dell'Era P, Mitola S, et al. Fibroblast growth factor/fibroblast growth factor receptor system in angiogenesis. Cytokine Growth Factor Rev 2005; 16: 159-178.

17 Brooks AN, Kilgour E, Smith PD. Molecular pathways: fibroblast growth factor signaling: a new therapeutic opportunity in cancer. Clin Cancer Res 2012; 18: 1855-1862.

18 Levitzki A. PDGF receptor kinase inhibitors for the treatment of PDGF driven diseases. Cytokine Growth Factor Rev 2004; 15: 229-235.

19 Beitz JG, Kim IS, Calabresi P, et al. Human microvascular endothelial cells express receptors for platelet-derived growth factor. Proc Natl Acad Sci USA 1991; 88: 2021-2025.

20 Wu E, Palmer N, Tian Z, et al. Comprehensive dissection of PDGF-PDGFR signaling pathways in PDGFR genetically defined cells. PLoS One 2008; 3: e3794.

21 Reck M, von Pawel J, Zatloukal P, et al. Phase III trial of cisplatin plus gemcitabine with either placebo or bevacizumab as first-line therapy for nonsquamous non-small-cell lung cancer: AVAil. J Clin Oncol 2009; 27: 1227-1234.

22 Reck M, von Pawel J, Zatloukal P, et al. Overall survival with cisplatin-gemcitabine and bevacizumab or placebo as first-line therapy for nonsquamous non-small-cell lung cancer: results from a randomised phase III trial (AVAiL). Ann Oncol 2010; 21: 1804-1809.

23 Goss GD, Arnold A, Shepherd FA, et al. Randomized, double-blind trial of carboplatin and paclitaxel with either daily oral cediranib or placebo in advanced non-small-cell lung cancer: NCIC clinical trials group BR24 study. J Clin Oncol 2010; 28: 49-55.

24 Laurie SA, Solomon BJ, Seymour L, et al. A randomized double-blind trial of carboplatin plus paclitaxel (CP) with daily oral cediranib (CED), an inhibitor of vascular endothelial growth factor receptors, or placebo (PLA) in patients (pts) with previously untreated advanced non-small cell lung cancer (NSCLC): NCIC Clinical Trials Group study BR29. J Clin Oncol 2012; 30: Suppl. 15, 7511.

25 Scagliotti G, Novello S, von Pawel J, et al. Phase III study of carboplatin and paclitaxel alone or with sorafenib in advanced non-small-cell lung cancer. J Clin Oncol 2010; 28: 1835-1842.

26 Paz-Ares LG, Biesma B, Heigener D, et al. Phase III, randomized, double-blind, placebo-controlled trial of gemcitabine/cisplatin alone or with sorafenib for the first-line treatment of advanced, nonsquamous non-small-cell lung cancer. J Clin Oncol 2012; 30: 3084-3092.

27 Scagliotti GV, Vynnychenko I, Park K, et al. International, randomized, placebo-controlled, double-blind phase III study of motesanib plus carboplatin/paclitaxel in patients with advanced nonsquamous non-small-cell lung cancer: MONET1. J Clin Oncol 2012; 30: 2829-2836.

28 Lara PN Jr, Douillard JY, Nakagawa K, et al. Randomized phase III placebo-controlled trial of carboplatin and paclitaxel with or without the vascular disrupting agent vadimezan (ASA404) in advanced non-small-cell lung cancer. J Clin Oncol 2011; 29: 2965-2971.

29 Ramalingam SS, Dahlberg SE, Langer CJ, et al. Outcomes for elderly, advanced-stage non small-cell lung cancer patients treated with bevacizumab in combination with carboplatin and paclitaxel: analysis of Eastern Cooperative Oncology Group Trial 4599. J Clin Oncol 2008; 26: 60-65.

30 Leighl NB, Zatloukal P, Mezger J, et al. Efficacy and safety of bevacizumab-based therapy in elderly patients with advanced or recurrent nonsquamous non-small cell lung cancer in the phase III BO17704 study (AVAiL). J Thorac Oncol 2010; 5: 1970-1976.

31 Hapani S, Sher A, Chu D, et al. Increased risk of serious hemorrhage with bevacizumab in cancer patients: a metaanalysis. Oncology 2010; 79: 27-38.

32 Crino L, Dansin E, Garrido P, et al. Safety and efficacy of first-line bevacizumab-based therapy in advanced nonsquamous non-small-cell lung cancer (SAiL, MO19390): a phase 4 study. Lancet Oncol 2010; 11: 733-740.

33 Dahlberg SE, Ramalingam SS, Belani CP, et al. A. randomized phase III study of maintenance therapy with bevacizumab (B), pemetrexed (Pm), or a combination of bevacizumab and pemetrexed (BPm) following carboplatin, paclitaxel and bevacizumab (PCB) for advanced nonsquamous NSCLC: ECOG trial 5508 (NCT01107626). J Clin Oncol 2011; 29: Suppl. 15, TPS218.

34 Gridelli C, Bennouna J, de Castro J, et al. Randomized phase IIIb trial evaluating the continuation of bevacizumab beyond disease progression in patients with advanced non-squamous non-small-cell lung cancer after first-line treatment with bevacizumab plus platinum-based chemotherapy: treatment rationale and protocol dynamics of the AvaALL (MO22097) trial. Clin Lung Cancer 2011; 12: 407-411.

35 Wakelee HA, Dahlberg SE, Keller SM, et al. Interim report of on-study demographics and toxicity from E1505, a phase III randomized trial of adjuvant (adj) chemotherapy (chemo) with or without bevacizumab (B) for completely resected early-stage non-small cell lung cancer (NSCLC). J Clin Oncol 2011; 29: Suppl. 15, 7013.

36 Wedge SR, Kendrew J, Hennequin LF, et al. AZD2171: a highly potent, orally bioavailable, vascular endothelial growth factor receptor-2 tyrosine kinase inhibitor for the treatment of cancer. Cancer Res 2005; 65: 4389-4400.

37 Wilhelm SM, Carter C, Tang L, et al. BAY 43-9006 exhibits broad spectrum oral antitumor activity and targets the RAF/MEK/ERK pathway and receptor tyrosine kinases involved in tumor progression and angiogenesis. Cancer Res 2004; 64: 7099-7109.

38 Polverino A, Coxon A, Starnes C, et al. AMG 706, an oral, multikinase inhibitor that selectively targets vascular endothelial growth factor, platelet-derived growth factor, and kit receptors, potently inhibits angiogenesis and induces regression in tumor xenografts. Cancer Res 2006; 66: 8715-8721. 
Rugo HS, Herbst RS, Liu G, et al. Phase I trial of the oral antiangiogenesis agent AG-013736 in patients with advanced solid tumors: pharmacokinetic and clinical results. J Clin Oncol 2005; 23: 5474-5483.

40 Schiller JH, Larson T, Ou SH, et al. Efficacy and safety of axitinib in patients with advanced non-small-cell lung cancer: results from a phase II study. J Clin Oncol 2009; 27: 3836-3841.

41 Twelves CJ, Chmielowska E, Havel L, et al. Randomised phase II study of axitinib or bevacizumab combined with paclitaxel/carboplatin as first-line therapy for patients with advanced non-small-cell lung cancer. Ann Oncol 2014; 25: 132-138.

42 Pfizer. Evaluation of the efficacy of the combination of axitinib with pemetrexed and cisplatin in the treatment of non-squamous non-small cell lung cancer. NCT00768755. http://clinicaltrials.gov/show/NCT00768755 Date last updated: March 28, 2013. Date last accessed: November 11, 2013.

43 Baguley BC, Siemann DW. Temporal aspects of the action of ASA404 (vadimezan; DMXAA). Expert Opin Investig Drugs 2010; 19: 1413-1425.

44 Reck M, Kaiser R, Mellemgaard A, et al. Nintedanib (BIBF 1120) plus docetaxel in NSCLC patients progressing after one prior chemotherapy regimen: results of Lume-Lung 1, a randomized, double-blind, phase III trial. J Clin Oncol 2013; 31: LBA8011.

45 Hanna NH, Kaiser R, Sullivan RN, et al. Lume-lung 2: a multicenter, randomized, double-blind, phase III study of nintedanib plus pemetrexed versus placebo plus pemetrexed in patients with advanced nonsquamous non-small cell lung cancer (NSCLC) after failure of first-line chemotherapy. J Clin Oncol 2013; 31: 8034.

46 Herbst RS, Sun Y, Eberhardt WE, et al. Vandetanib plus docetaxel versus docetaxel as second-line treatment for patients with advanced non-small-cell lung cancer (ZODIAC): a double-blind, randomised, phase 3 trial. Lancet Oncol 2010; 11: 619-626.

47 de Boer $\mathrm{RH}$, Arrieta $\mathrm{O}$, Yang $\mathrm{CH}$, et al. Vandetanib plus pemetrexed for the second-line treatment of advanced non-small-cell lung cancer: a randomized, double-blind phase III trial. J Clin Oncol 2011; 29: 1067-1074.

48 Lee JS, Hirsh V, Park K, et al. Vandetanib versus placebo in patients with advanced non-small-cell lung cancer after prior therapy with an epidermal growth factor receptor tyrosine kinase inhibitor: a randomized, double-blind phase III trial (ZEPHYR). J Clin Oncol 2012; 30: 1114-1121.

49 Natale RB, Thongprasert S, Greco FA, et al. Phase III trial of vandetanib compared with erlotinib in patients with previously treated advanced non-small-cell lung cancer. J Clin Oncol 2011; 29: 1059-1066.

50 Paz-Ares L, Hirsh V, Zhang L, et al. Monotherapy administration of sorafenib in patients with non-small cell lung cancer: phase III randomized, double-blind, placebo-controled MISSION trial. Ann Oncol 2012; 23: Suppl. 9, LBA33_PR.

51 Scagliotti GV, Krzakowski M, Szczesna A, et al. Sunitinib plus erlotinib versus placebo plus erlotinib in patients with previously treated advanced non-small-cell lung cancer: a phase III trial. J Clin Oncol 2012; 30: 2070-2078.

52 Herbst RS, Ansari R, Bustin F, et al. Efficacy of bevacizumab plus erlotinib versus erlotinib alone in advanced nonsmall-cell lung cancer after failure of standard first-line chemotherapy (BeTa): a double-blind, placebo-controlled, phase 3 trial. Lancet 2011; 377: 1846-1854.

53 Ramlau R, Gorbunova V, Ciuleanu TE, et al. Aflibercept and docetaxel versus docetaxel alone after platinum failure in patients with advanced or metastatic non-small-cell lung cancer: a randomized, controlled phase III trial. J Clin Oncol 2012; 30: 3640-3647.

54 Hilberg F, Roth GJ, Krssak M, et al. BIBF 1120: triple angiokinase inhibitor with sustained receptor blockade and good antitumor efficacy. Cancer Res 2008; 68: 4774-4782.

55 Kutluk Cenik B, Ostapoff KT, Gerber DE, et al. BIBF 1120 (nintedanib), a triple angiokinase inhibitor, induces hypoxia but not EMT and blocks progression of preclinical models of lung and pancreatic cancer. Mol Cancer Ther 2013; 12: 992-1001.

56 Ellis PM, Kaiser R, Zhao Y, et al. Phase I open-label study of continuous treatment with BIBF 1120, a triple angiokinase inhibitor, and pemetrexed in pretreated non-small cell lung cancer patients. Clin Cancer Res 2010; 16: 2881-2889.

57 Doebele RC, Conkling P, Traynor AM, et al. A phase I open-label dose-escalation study of continuous treatment with BIBF 1120 in combination with paclitaxel and carboplatin as first-line treatment in patients with advanced non-small-cell lung cancer. Ann Oncol 2012; 23: 2094-2102.

58 Reck M, Kaiser R, Eschbach C, et al. A phase II double-blind study to investigate efficacy and safety of two doses of the triple angiokinase inhibitor BIBF 1120 in patients with relapsed advanced non-small-cell lung cancer. Ann Oncol 2011; 22: 1374-1381.

59 Wedge SR, Ogilvie DJ, Dukes M, et al. ZD6474 inhibits vascular endothelial growth factor signaling, angiogenesis, and tumor growth following oral administration. Cancer Res 2002; 62: 4645-4655.

60 Molina JR, Dy GK, Foster NR, et al. A. randomized phase II study of pemetrexed (PEM) with or without sorafenib (S) as second-line therapy in advanced non-small cell lung cancer (NSCLC) of nonsquamous histology: NCCTG N0626 study. J Clin Oncol 2011; 29: 7513.

61 Sun L, Liang C, Shirazian S, et al. Discovery of 5-[5-fluoro-2-oxo-1,2-dihydroindol-(3Z)-ylidenemethyl]-2,4dimethyl-1H-pyrrole-3-carboxylic acid (2-diethylaminoethyl)amide, a novel tyrosine kinase inhibitor targeting vascular endothelial and platelet-derived growth factor receptor tyrosine kinase. J Med Chem 2003; 46: 1116-1119.

62 Heist RS, Wang XF, Hodgson L, et al. CALGB 30704: a randomized phase II study to assess the efficacy of pemetrexed or sunitinib or pemetrexed plus sunitinib in the second-line treatment of advanced non-small cell lung cancer (NSCLC). J Clin Oncol 2012; 30: Suppl. 15, 7513.

63 Novartis International AG. Press release: Novartis discontinues ASA404 clinical trial program and shifts focus to other cancer compounds in early and late stage development. http://hugin.info/134323/R/1461276/400465.pdf Date last updated: November 11, 2010. Date last accessed: November 11, 2013.

64 Spratlin JL, Mulder KE, Mackey JR. Ramucirumab (IMC-1121B): a novel attack on angiogenesis. Future Oncol 2010; 6: 1085-1094.

65 Camidge DR, Ballas MS, Dubey S, et al. A phase II, open-label study of ramucirumab (IMC-1121B), an IgG1 fully human monoclonal antibody (MAb) targeting VEGFR-2, in combination with paclitaxel and carboplatin as firstline therapy in patients (pts) with stage IIIb/IV non-small cell lung cancer (NSCLC). J Clin Oncol 2010; 28 : Suppl. 15, 7588 . 
66 Eli Lilly and Co. A study of pemetrexed and carboplatin/cisplatin or gemcitabine and carboplatin/cisplatin with or without IMC-1121B in patients previously untreated with recurrent or advanced non-small cell lung cancer (NSCLC). NCT01160744. http://clinicaltrials.gov/show/NCT01160744. Date last updated: December 17, 2013. Date last accessed: November 11, 2013.

67 Garon EB, Cao D, Alexandris E, et al. A randomized, double-blind, phase III study of docetaxel and ramucirumab versus docetaxel and placebo in the treatment of stage IV non-small-cell lung cancer after disease progression after 1 previous platinum-based therapy (REVEL): treatment rationale and study design. Clin Lung Cancer 2012; 13: 505-509.

68 Gadgeel SM, Ruckdeschel JC, Wozniak AJ, et al. Cediranib, a VEGF receptor 1, 2, and 3 inhibitor, and pemetrexed in patients (pts) with recurrent non-small cell lung cancer (NSCLC). J Clin Oncol 2011; 29: Suppl. 15, 7564.

69 Sloan B, Scheinfeld NS. Pazopanib, a VEGF receptor tyrosine kinase inhibitor for cancer therapy. Curr Opin Investig Drugs 2008; 9: 1324-1335.

70 Loyola University. Stage IIIB/IV non-small cell lung cancer. NCT01179269. http://clinicaltrials.gov/show/ NCT01179269. Date last updated: October 29, 2012. Date last accessed: November 11, 2013.

71 UNC Lineberger Comprehensive Cancer Center. Pazopanib in stage IIIB/IV NSCLC lung cancer after progression on first line therapy containing bevacizumab (LCCC0921). NCT01107652. www.clinicaltrials.gov/show/ NCT01107652. Date last updated: March 4, 2013. Date last accessed: November 11, 2013.

72 GlaxoSmithKline. A study to evaluate pazopanib in comparison to pemetrexed in maintenance setting in nonprogressing subjects with metastatic stage IVA and IVB non-squamous non-small cell lung cancer (NSCLC) population. NCT01313663. http://clinicaltrials.gov/show/NCT01313663. Date last updated: October 4, 2013. Date last accessed: November 11, 2013.

73 Infante JR, Novello S, Ma WW, et al. Phase Ib trial of the oral angiogenesis inhibitor pazopanib administered concurrently with pemetrexed in patients with advanced solid tumors. Invest New Drugs 2013; 31: 927-936.

74 Altorki N, Lane ME, Bauer T, et al. Phase II proof-of-concept study of pazopanib monotherapy in treatment-naive patients with stage I/II resectable non-small-cell lung cancer. J Clin Oncol 2010; 28: 3131-3137.

75 Shankar DB, Li J, Tapang P, et al. ABT-869, a multitargeted receptor tyrosine kinase inhibitor: inhibition of FLT3 phosphorylation and signaling in acute myeloid leukemia. Blood 2007; 109: 3400-3408.

76 Tan EH, Goss GD, Salgia R, et al. Phase 2 trial of linifanib (ABT-869) in patients with advanced non-small cell lung cancer. J Thorac Oncol 2011; 6: 1418-1425.

77 Ramalingam SS, Shtivelband M, Soo RA, et al. Randomized phase II study of carboplatin and paclitaxel with either linifanib or placebo for advanced nonsquamous NSCLC. J Clin Oncol 2012; 30: 7512.

78 Pao W, Girard N. New driver mutations in non-small-cell lung cancer. Lancet Oncol 2011; 12: 175-180.

79 Cancer Genome Atlas Research Network. Comprehensive genomic characterization of squamous cell lung cancers. Nature 2012; 489: 519-525.

80 Gadgeel SM. Safety profile and tolerability of antiangiogenic agents in non-small-cell lung cancer. Clin Lung Cancer 2012; 13: 96-106. 